\title{
Trace elements concentrations in Buff-breasted Sandpiper sampled in Lagoa do Peixe National Park, Southern Brazil
}

\author{
J. F. M. Scherer ${ }^{a *}$, A. L. Scherer ${ }^{a}$, E. Barbieri ${ }^{b}$, M. V. Petry ${ }^{c}$ and V. H. Valiati $^{a}$ \\ áLaboratório de Biologia Molecular, Programa de Pós-Graduação em Biologia, Centro de Ciências da Saúde, \\ Universidade do Vale do Rio dos Sinos - Unisinos, Avenida Unisinos, 950, sala 2C, 116, CP 275, CEP 93022-000, \\ São Leopoldo, RS, Brazil \\ 'Instituto de Pesca - APTA-SAA/SP, Avenida Professor Besnard, s/n, CP 61, CEP 11900-000, Cananéia, SP, Brazil \\ ${ }^{c}$ Laboratório de Ornitologia e Animais Marinhos, Programa de Pós-Graduação em Biologia, \\ Centro de Ciências da Saúde, Universidade do Vale do Rio dos Sinos - Unisinos, Avenida Unisinos, 950, \\ Sala 2D223, CP 275, CEP 93022-000, São Leopoldo, RS, Brazil \\ *e-mail: netscherer@gmail.com
}

Received: February 19, 2014 - Accepted: August 2, 2014 - Distributed: November 30, 2015

\begin{abstract}
Cadmium, cobalt, chromium, copper, manganese, nickel, zinc and lead concentrations were detected in feathers of Buff-breasted Sandpipers (Calidris subruficollis) captured during the non-breeding season and analyzed with relationship to body mass. Of these metals tested for, only copper levels $(2.28 \mu \mathrm{g} / \mathrm{g})$ were positively correlated with bird body mass. Zinc levels showed higher concentration $(67.97 \mu \mathrm{g} / \mathrm{g})$ than the other metals, and cadmium levels showed the lowest concentration $(0.14 \mu \mathrm{g} / \mathrm{g})$. Trace element concentrations were below toxicity levels for all tested chemicals and we suggest that this probably reflects that essential elements are maintained there by normal homeostatic mechanism and that no excessive environmental exposure to these elements during migration or on the wintering area is suggested by these results.
\end{abstract}

Keywords: Charadriiformes, contaminants, body mass, wintering area, shorebirds.

\section{Concentração de elementos-traço em maçarico-acanelado amostrados no Parque Nacional da Lagoa do Peixe, Sul do Brasil}

\section{Resumo}

As concentrações de cádmio, cobalto, cromo, cobre, manganês, níquel, zinco e chumbo foram detectadas em penas de Maçarico-acanelado (Calidris subruficollis) capturados durante o período de invernada e analisados em relação a massa corporal. Destes metais analisados, somente os níveis de cobre $(2,28 \mu \mathrm{g} / \mathrm{g})$ foram correlacionados positivamente com a massa corporal dos indivíduos. Níveis de zinco apresentaram-se mais altos $(67,97 \mu \mathrm{g} / \mathrm{g})$ que outros metais e os níveis de cádmio apresentaram as menores concentrações $(0,14 \mu \mathrm{g} / \mathrm{g})$. As concentrações dos elementos-traços estão abaixo dos níveis de toxicidade em todos os testes químicos e sugerimos que isto provavelmente ocorre pela manutenção dos elementos essenciais através do mecanismo normal de homeostase e não reflete a exposição destes elementos durante a migração ou nas áreas de invernada.

Palavras-chave: Charadriiformes, contaminação, massa corporal, área de invernada, aves costeiras.

\section{Introduction}

Habitats selected by shorebirds along their migration routes are diverse and vary in quality with relation to species eating requirements, availability and productivity of food resources, and foraging tactics), as well as risk of predation while on the site (Lunardi et al., 2012). During the migration, birds are more susceptible to contamination, given that they are exposed to different environments along the flyway (Hargreaves et al., 2010; Torres-Dowdall et al., 2010). They can be contaminated through direct contact with heavy metals (Warnock and
Takekawa, 1996; Lanctot et al., 2002), or by the consumption of contaminated prey (Burger et al., 2001; Kim and Koo, 2008). High level contamination by trace metal elements may negatively affect the reproduction and the general health of some birds (Dauwe et al., 2004), as well as may cause death of individuals (Bull et al., 1983). In this way, anthropogenic factors, such as chemicals and pollutants, can contribute to causing continental level declines of migrant shorebird populations (Zöckler et al., 2003). 
Buff-breasted Sandpiper (Calidris subruficollis), (Vieillot, 1819) has continued a population decline which began with commercial hunting in the last century, and has continued that decline in the present century due to habitat loss and to contamination from spilled oil, gas and other toxic agents (Lanctot et al., 2010; Andres et al., 2012; Cosewic, 2012; Lounsberry et al., 2013) leading to the species being currently classified as "Near Threatened Status" (Birdlife International, 2014). The species migrate from their breeding grounds in Alaska and Canada to winter in the pampas of South America (Lanctot et al., 2002; Norling et al., 2012), at places such as Lagoa do Peixe National Park (LPNP) and surrounding sites (Resende and Leeuwenberg, 1987; Scherer and Petry, 2012; Harrison et al., 2013). The LPNP is an important reserve because protects one of South America's most outstanding refuges for long-distance migrants (WHSRN, 2014). One of the main reasons that high concentrations of shorebirds use the lagoon is presumably the availability of food resources and sites for replacement, where individuals can gain weight to complete the migration process between hemispheres.

Feathers are useful for measuring levels of trace elements in birds without causing harm to the individual (Furness and Greenwood, 1993). This makes it possible to use them for studies correlating trace elements with individual body mass (Burger et al., 1993; Lucia et al., 2012). The goal of this study was to determine trace element levels of six metals in Buff-breasted Sandpiper and attempt to correlate them with birds body mass.

\section{Material and Methods}

Shorebird catches were conducted in pasturelands in the Lagoa do Peixe National Park (LPNP) (31 ${ }^{\circ} 15^{\prime}$ ' 9 ' S, $050^{\circ} 58^{\prime} 19^{\prime} \mathrm{W}$ ) in spring 2011. In the field, Buff-breasted Sandpipers were weighed; a blood sample collected, and one primary and a few breast feathers were collected from each bird and stored in sealed plastic bags. We analyzed cadmium, cobalt, chromium, copper, manganese, nickel, zinc, and lead according methods used by Barbieri et al. (2010). All element concentrations $(\mu \mathrm{g} / \mathrm{g})$ in feathers were expressed as dry weight basis. Genomic DNA was extracted from red blood cells using the standard phenol/chloroform and proteinase K extraction followed by ethanol precipitation (Sambrook et al., 2001). Thereafter, the gene CHD1 (chromo-helicase-DNA-binding 1) was amplified by polymerase chain reaction (PCR), using primers P2 and P8 (Griffiths et al., 1998) to identify sex of each bird. A Pearson correlation test was performed to analyse element correlations with weight. The significance level was set at $\mathrm{p}<0.05$ for analyse.

\section{Results}

We analyzed feathers of 29 Buff-breasted Sandpiper, being 7 males, 17 females and, 5 undetermined. Concentration levels of trace elements tested for in feathers were below toxicity levels for all individuals and average values are presented in Table 1. Nickel and chromium concentrations were below the detection level for all samples. Pearson correlation tests showed that copper was positively correlated with Buff-breasted Sandpiper body mass $(\mathrm{r}=0.375, \mathrm{p}=0.045)$.

\section{Discussion}

All trace element levels found in this study were below the toxic range reported in the literature (Vermeer and Castilla, 1991; Puls, 1994; Burger et al., 2001; Barbieri et al., 2007; Kim and Oh, 2013). Essential elements are present in all living organisms and necessary for regulation of body functions and are usually maintained by homeostasis mechanisms, which act in the removal of excess and maintenance of normal bodily concentrations (Kim and Oh, 2013). Therefore, low levels of these components result from a good intrinsic regulatory system, and it is suggested that this process can regulate chromium, cobalt, copper, manganese, nickel, and zinc. Significant copper levels correlation with body mass may reflect that these shorebirds, when compared with other birds, may use more energy by keeping higher metabolic rates (Colwell, 2010) and ingest higher prey mass. Thus, copper level being correlated with body mass may have arisen from bioaccumulation via species-specific metabolism and it is thought to be unlikely reflect pollution or higher natural background level of copper in their habitats (Kim et al., 1996).

Table 1. Values of trace elements concentrations (mean \pm SD, $\mu \mathrm{g} / \mathrm{g}$ ) in feathers of Buff-breasted Sandpiper $(\mathrm{n}=29)$ and other bird species.

\begin{tabular}{cccccccc}
\hline $\mathbf{C d}$ & $\mathbf{C o}$ & $\mathbf{C u}$ & $\mathbf{M n}$ & $\mathbf{P b}$ & $\mathbf{Z n}$ & Species & Source \\
\hline $0.15 \pm 0.10$ & $3.31 \pm 1.10$ & $2.29 \pm 0.95$ & $3.72 \pm 4.19$ & $2.18 \pm 0.63$ & $67.97 \pm 8.45$ & $\begin{array}{c}\text { C. } \\
\text { subruficollis }\end{array}$ & Present study \\
\hline 0.072 & 4.49 & 13.30 & 11.36 & 7.54 & 68.97 & $\begin{array}{c}\text { Larus } \\
\text { dominicaus }\end{array}$ & $\begin{array}{c}\text { Barbieri et al. } \\
(2010)\end{array}$ \\
\hline 0.09 & - & - & 1.10 & 1.25 & - & $\begin{array}{c}\text { Haematopus } \\
\text { bachmani }\end{array}$ & $\begin{array}{c}\text { Burger et al. } \\
(2008)\end{array}$ \\
\hline 0.07 & - & 14.93 & - & 2.79 & 207.97 & $\begin{array}{c}\text { Limosa } \\
\text { limosa }\end{array}$ & $\begin{array}{c}\text { Roodbergen et al. } \\
(2008)\end{array}$ \\
\hline 0.70 & - & - & 2.96 & 2.26 & - & $\begin{array}{c}\text { Calidris } \\
\text { pusilla }\end{array}$ & $\begin{array}{c}\text { Burger et al. } \\
(1993)\end{array}$ \\
\hline
\end{tabular}


Levels of non-essential elements such as cadmium and lead were found in individuals. According to Scherer et al. (unpublished data), cadmium levels found in sediment of LPNP were about $0.02 \mu \mathrm{g} / \mathrm{g}$. Therefore we cannot say with certainty where this exposure occurred, but what we can say, is that in our study, the individuals all evidenced low cadmium concentrations and that their exposure does not reflect levels of bioaccumulation during wintering in the park, suggesting that the levels found in individuals are not sufficient to cause damage to them. According to Burger et al. (2001), for terns, the toxicity levels must be above $2 \mu \mathrm{g} / \mathrm{g}$ before sublethal effects are noted, and the individuals in our study showed concentrations far below this $(0.15 \mu \mathrm{g} / \mathrm{g})$. Another hand, according to Clark and Scheuhammer (2003), lead concentrations between 2.0 and $10.0 \mu \mathrm{g} / \mathrm{g}$ are associated with exposure to lead pollution. Although low lead concentrations were found in our study $(2.18 \mu \mathrm{g} / \mathrm{g})$, this level is indicative of exposure of these individuals to this metal, but without toxicological risk, and thus it could be considered as the background level (Kim and Oh, 2013). Our study is the first to evaluate trace elements in Buff-breasted Sandpiper in LPNP and contributes valuable information because we showed that metallic trace element levels found in the birds captured in park are below the range of considered toxic, and do not show excessive bioaccumulation, thus retaining normal traces element levels. Further studies in regularly used shorebird wintering areas will be important to determine the degree of heavy metal contamination on a timescale, as well as whether some of these sites might interfere in birds' health and population stability. Performing studies like this can serve as an important tool for monitoring wintering areas, serving as a conservation tool for both habitats and for species that use them.

\section{Acknowledgements}

We thank CEMAVE staff and, ICMBio Lagoa do Peixe National Park staff for helping in the fieldwork. The research was supported by CNPq, CAPES, FAPERGS and, UNISINOS. We appreciate the improvements in English usage made by Phil Whitford through the Association of Field Ornithologists' program of editorial assistance. All individuals were banded with a steel ring under CEMAVE permission $n^{\circ} 3221 / 2010$. Blood samples were taken under ICMBio permission $n^{\circ} 23159 / 2010$.

\section{References}

ANDRES, B.A., SMITH, P.A., MORRISON, R.I.G., GRATTOTREVOR, C.L., BROWN, S.C. and FRIIS, C.A., 2012. Population estimates of North American Shorebirds, 2012. Wader Study Group Bulletin, vol. 119, no. 3, pp. 178-194.

BARBIERI, E., PASSOS, E.A., FILIPPINI, A., SANTOS, I.S. and GARCIA, C.A.B., 2010. Assessment of trace metal concentration in feathers of seabird (Larus dominicanus) sampled in the Florianópolis, SC, Brazilian coast. Environmental Monitoring and Assessment, vol. 169, no. 1-4, pp. 631-638. http://dx.doi. org/10.1007/s10661-009-1202-4. PMid:19856122.

BARBIERI, E., GARCIA, C.A.B., PASSOS, E.A., ARAGÃO, K.A.S. and KENNEDY, A.S., 2007. Heavy metal concentration in tissues of Puffinus gravis sampled on the Brazilian coast. Revista Brasileira de Ornitologia, vol. 15, no. 28, pp. 69-72.

BIRDLIFE INTERNATIONAL, 2014 [viewed 01 January 2014] Species factsheet: Tryngites subruficollis. BirdLife International [online]. Available from: http://www.birdlife.org/datazone/species/ factsheet $/ 22693447$

BULL, K.R., EVERY, W.J., FREESTONE, P., HALL, J.R., OSBORN, D., COOKE, A.S. and STOWE, T., 1983. Alkyl lead pollution and bird mortalities on the Mersey Estuari, UK, 19791981. Environmental Pollution, vol. 31, no. 4, pp. 239-259. http:// dx.doi.org/10.1016/0143-1471(83)90062-4.

BURGER, J., GOCHFELD, M., SULLIVAN, K., IRONS, D. and MCKNIGHT, A., 2008. Arsenic, cadmium, chromium, lead, manganese, mercury, and selenium in feathers of Black-legged Kittiwake (Rissa tridactyla) and Black Oystercatcher (Haematopus bachmani) from Prince William Sound, Alaska. The Science of the Total Environment, vol. 398, no. 1-3, pp. 20-25. http://dx.doi. org/10.1016/j.scitotenv.2008.02.051. PMid:18440597.

BURGER, J., SHUKLA, T., DIXON, C., SHUKLA, S., MCMAHON, M.J., RAMOS, R. and GOCHFELD, M., 2001. Metals in feathers of sooty tern, white tern, gray-backed tern, and brown noddy from islands in the North Pacific. Environmental Monitoring and Assessment, vol. 71, no. 1, pp. 71-89. http://dx.doi. org/10.1023/A:1011695829296. PMid:11589497.

BURGER, J., SEYBOLDT, S., MORGANSTEIN, N. and CLARK, K., 1993. Heavy metals and selenium in feathers of three shorebird species from Delaware bay. Environmental Monitoring and Assessment, vol. 28, no. 2, pp. 189-198. http:// dx.doi.org/10.1007/BF00547037. PMid:24221132.

CLARK, A.J. and SCHEUHAMMER, A.M., 2003. Lead poisoning in upland-foraging birds of prey in Canada. Ecotoxicology, vol. 12, no. 1-4, pp. 23-30. http://dx.doi.org/10.1023/A:1022576510445. PMid:12739854

COLWELL, M.A., 2010. Shorebird ecology, conservation and management. London: University of California Press. 328 p.

COMMITTEE ON THE STATUS OF ENDANGERED WILDLIFE IN CANADA - COSEWIC, 2012. COSEWIC assessment and status report on the Buff-breasted sandpiper Tryngites subruficollis in Canada. Ottawa: COSEWIC. 44 p.

DAUWE, T., JANSSENS, E., KEMPENAERS, B. and EENS, M., 2004. The effect of heavy metal exposure on egg size, eggshell thickness and the number of spermatozoa in blue tit Parus caeruleus eggs. Environmental Pollution, vol. 129, no. 1, pp. 125-129. http://dx.doi.org/10.1016/j.envpol.2003.09.028. PMid:14749076.

FURNESS, R.W. and GREENWOOD, J.J.D., 1993. Birds as monitors of environmental change. London: Chapman and Hall. 356 p.

GRIFFITHS, R., DOUBLE, M.C., ORR, K. and DAWSON, R.J.G., 1998. A DNA test to sex most birds. Molecular Ecology, vol. 7, no. 8, pp. 1071-1075. http://dx.doi.org/10.1046/j.1365294x.1998.00389.x. PMid:9711866.

HARGREAVES, A.L., WHITESIDE, D.P. and GILCHRIST, G., 2010. Concentrations of 17 elements, including mercury, and their relationship to fitness measures in arctic shorebirds and their eggs. The Science of the Total Environment, vol. 408, no. 16, pp. 
3153-3161. http://dx.doi.org/10.1016/j.scitotenv.2010.03.027. PMid:20434755.

HARRISON, N.M., WHITEHOUSE, M.J. and MADUREIRA, A.S.P., 2013. Observations of the under-described avifauna of the Mostardas Peninsula, Rio Grande do Sul, Brazil. Check list, vol. 9, no. 2, pp. 391-399. http://dx.doi.org/10.15560/9.2.391.

KIM, J. and OH, J.M., 2013. Assessment of trace metals in four bird species from Korea. Environmental Monitoring and Assessment, vol. 185, no. 8, pp. 6847-6854. http://dx.doi.org/10.1007/s10661013-3069-7. PMid:23430066.

KIM, J. and KOO, T.H., 2008. Heavy metal concentrations in feathers of Korean shorebirds. Archives of Environmental Contamination and Toxicology, vol. 55, no. 1, pp. 122-128. http://dx.doi.org/10.1007/s00244-007-9089-y. PMid:18080082.

KIM, E.Y., ICHIHASHI, H., SAEKI, K., ATRASHKEVICH, G., TANABE, S. and TATSUKAWA, R., 1996. Metal accumulation in tissues of seabirds from Chaun, northeast Siberia, Russia. Environmental Pollution, vol. 92, no. 3, pp. 247-252. http:// dx.doi.org/10.1016/0269-7491(96)00007-3. PMid:15091375.

LANCTOT, R.B., ALDABE, J., ALMEIDA, J.B., BLANCO, D., ISACCH, J.P., JORGENSEN, J., NORLAND, S., ROCCA, P. and STRUM, K.M., 2010. Conservation plan for the buff-breasted sandpiper (Tryngites subruficollis). Anchorage, Alaska: Fish and Wildlife Service; Manomet, Massachusetts: Manomet Center for Conservation Sciences. 114 p. Version 1.1. U. S

LANCTOT, R.B., BLANCO, D.E., DIAS, R.A., ISACCH, J.P., GILL, V.A., ALMEIDA, J.B., DELHEY, K., PETRACCI, P.F., BENCKE, G.A. and BALBUENO, R.A., 2002. Conservation status of the Buff-Breasted Sandpiper: historic and contemporary distribution and abundance in South America. The Wilson Bulletin, vol. 114 , no. 1 , pp. 44-72. http://dx.doi.org/10.1676/00435643(2002)114[0044:CSOTBB]2.0.CO;2.

LOUNSBERRY, Z.T., ALMEIDA, J.B., GRACE, T., LANCTOT, R.B., LIEBEZEIT, J., SANDERCOCK, B.K., STRUM, K.M., ZACK, S. and WISELY, S.M., 2013. Range-wide conservation genetics of Burr-breasted Sandpipers (Tryngites subruficollis). The Auk, vol. 130, no. 3, pp. 429-439. http://dx.doi.org/10.1525/ auk.2013.12206.

LUCIA, M., BOCHER, P., COSSON, R.P., CHURLAUD, C. and BUSTAMANTE, P., 2012. Evidence of species-specific detoxification processes for trace elements in shorebirds. Ecotoxicology, vol. 21, no. 8, pp. 2349-2362. http://dx.doi.org/10.1007/s10646-0120991-3. PMid:23001427.

LUNARDI, V.O., MACEDO, R.H., GRANADEIRO, J.P. and PALMEIRIM, J.M., 2012. Migratory flows and foraging habitat selection by shorebirds along the northeastern coast of Brazil: the case of Baía de Todos os Santos. Estuarine, Coastal and
Shelf Science, vol. 96, pp. 179-187. http://dx.doi.org/10.1016/j. ecss.2011.11.001.

NORLING, W., JESKE, C.W., THIGPEN, T.F. and CHADWICK, P.C., 2012. Estimating shorebird population during spring stopover in rice fields of the Louisiana and Texas Gulf Coastal Plain. Waterbirds, vol. 35, no. 3, pp. 361-370. http://dx.doi. org/10.1675/063.035.0301.

PULS, R., 1994. Mineral levels in animal health: diagnostic data. British Columbia: Sherpa International. 356 p.

RESENDE, S.L. and LEEUWENBERG, F., 1987. Ecological studies of Lagoa do Peixe. Washington: World Wildlife Foundation-WWF. 52 p. Unpublished Report 4.

ROODBERGEN, M., KLOK, C. and VAN DER HOUT, A., 2008. Transfer of heavy metals in the food chain earthworm Black-tailed godwit (Limosa limosa): comparison of a polluted and a reference site in The Netherlands. The Science of the Total Environment, vol. 406, no. 3, pp. 407-412. http://dx.doi. org/10.1016/j.scitotenv.2008.06.051. PMid:18752837.

SAMBROOK, K.J., RUSSEL, D.W. and SAMBROOK, J., 2001. Molecular cloning: a laboratory manual. New York: CSHL. 2100 p.

SCHERER, AL. and PETRY, MV., 2012. Seasonal variation in shorebird abundance in the State of Rio Grande do Sul, Southern Brazil. The Wilson Journal of Ornithology, vol. 124, no. 1, pp. 40-50. http://dx.doi.org/10.1676/11-034.1.

TORRES-DOWDALL, J., FARMER, A.H., ABRIL, M., BUCHER, E.H. and RIDLEY, I., 2010. Trace elements have limited utility for studying migratory connectivity in shorebirds that winter in Argentina. The Condor, vol. 112, no. 3, pp. 490-498. http://dx.doi. org/10.1525/cond.2010.090166.

VERMEER, K. and CASTILLA, J.C., 1991. High cadmium residues observed during a pilot study in shorebirds and their prey downstream from the El Salvador Copper Mine, Chile. Bulletin of Environmental Contamination and Toxicology, vol. 46, no. 2, pp. 242-248. http://dx.doi.org/10.1007/BF01691944. PMid:2018870.

WARNOCK, S.E.G. and TAKEKAWA, J.Y., 1996. Wintering site fidelity and movement patterns of western sandpipers (Calidris mauri) in the San Francisco Bay estuary. The Ibis, vol. 138, no. 2, pp. 160-167. http://dx.doi.org/10.1111/j.1474-919X.1996.tb04323.x.

WESTERN HEMISPHERE SHOREBIRD RESERVE NETWORK - WHSRN, 2014 [viewed 06 July 2014]. Lagoa do Peixe - about us. WHSRN [online]. Available from: http://www.whsrn.org/ site-profile/lagoa-do-peixe.

ZÖCKLER, C., DELANY, S. and HAGEMEIJER, W., 2003. Wader populations are declining - how will we elucidate the reasons? Wader Study Group Bulletin, vol. 100, pp. 202-211. 